\title{
Waterpipe tobacco smoking: A mini-review
}

\author{
Sankalp Yadav ${ }^{1}$, Gautam Rawal ${ }^{2}$, \\ 'General Duty Medical Officer-II, Department of Medicine \& TB, Chest Clinic Moti Nagar, North Delhi Municipal \\ Corporation, New Delhi, India; \\ ${ }^{2}$ Attending Consultant, Department of Respiratory Intensive Care, Max Hospital, Saket, New Delhi, India
}

\section{ABSTRACT}

The waterpipe tobacco smoking is an ancient form of smoking that is present in the society since centuries. The majority of consumers of this exotic activity are still unaware of the serious consequences that this type of smoking has on the health of the smoker. The paucity of data related to the prevalence and extent of this habit in the society is still not available. In this present short review, the authors try to highlight this serious health issue and suggest preventive measures.

Key words: hookah, public health, narghile, smoking, shisha, tobacco

Waterpipe tobacco smoking (WTS) is a global health concern and is an alternative form of tobacco use that involves passing tobacco smoke through water before inhalation. ${ }^{[1,2]}$ WTS is a traditional type of smoking that is present for many centuries. ${ }^{[3]}$ The WTS first started in India and later spread to the whole world. ${ }^{[4-6]}$ The recent reports from the last two decades show a much higher prevalence of this serious health issue from the developed world as well. $^{[4,7-10]}$

The WTS is known around the world by many different names and slightly different forms: hookah, hubble-bubble, kalian, nargeela, argeela, arghileh, shisha, sheesha, okka, nargileh, boury, ghelyoon, ghalyan, and gouza. ${ }^{[4]}$ The original form of WTS included only tobacco but later a number of alterations mainly related to addition of flavors and smell were done ${ }^{[4]}$ Recently, Hookah smoking has been identified by the public health officials as a new tobacco epidemic. ${ }^{[3]}$

For many decades, the WTS was dominated by males. ${ }^{[4,11-14]}$ However, this is not always true, as reports of female waterpipe tobacco (WT) smokers are also available from various parts of the world. ${ }^{44,5,10}$, ${ }^{11,15-17]}$ Previous studies in the US also show a large variation in proportion of WTS according to gender. ${ }^{[4,13,18,19]}$ The most common W'T smokers are usually those persons who have at least smoked cigarette, although it may not always be true. ${ }^{[4,19,20]}$ Various studies reported about the perception among the WT smokers that it is less harmful compared to the cigarette. ${ }^{[13,18-22]}$ WTS is not a safe alternative to cigarettes. ${ }^{[23]}$ The data about the perception of WTS among the consumers is sparse. ${ }^{[4]}$ Besides, the available scientific literature shows marked variations in the perception of this habit among W'T smokers from various parts of the globe. ${ }^{[4]}$ A section of WT smokers believes that WTS is harmless as they think that water filters out the smoke. ${ }^{[4,18,20,24-27]}$ However, detailed studies related to this perception are lacking. ${ }^{[4]}$

Due to the less irritating nature of the moisturized smoke, the WT smokers can smoke for 30 minutes to a few hours and inhale more deeply. ${ }^{[28]}$ There is evidence that those who are occasional or regular W'T smokers are more likely to become regular cigarette smokers, suggesting that WTS may be a potential entryway for regular cigarette smoking. ${ }^{[29]}$ Also, a number of reports of non-smokers sharing a table or sitting at a place where W'TS is done resort to W'TS in future. ${ }^{[4,13,19]}$

It is well established that when compared to cigarette smoking, the number of puffs 
and volume from using W'T are about 10 times higher than cigarettes. ${ }^{[4]}$ As per the CDC, a typical 1-hour-long WT smoking session involves 200 puffs, while an average cigarette is 20 puffs. ${ }^{[30]}$ Thus toxicant yields during $1-2$ hours WTS was comparable to 100-200 cigarettes. The volume of smoke inhaled during a typical WTS session is about 90,000 milliliters, compared with 500-600 milliliters inhaled when smoking a cigarette. ${ }^{[30]} \mathrm{W}^{\prime} \mathrm{T}$ smoke also contains 36 times the amount of nicotine and much higher concentrations of heavy metals. ${ }^{[4,15,23]}$ And the burning temperature of tobacco for WTS is about $900^{\circ}$, compared to $450^{\circ}$ for cigarettes, thus WTS could produce different type and levels of harmful chemicals and tar. ${ }^{[23]}$ Further, exhaled CO levels from WTS users were twice as high as cigarette smokers in cessation programs. ${ }^{[4,18]}$ These all harmful ingredients of the WTS has serious effects on the health of the user. Also, the WTS during pregnancy can result in the low birth weight baby. ${ }^{[31]}$ The effects of secondhand smoke from WTS are just similar to that arising from the cigarette smoke. ${ }^{[4]}$ Besides, the WTS can also lead to a number of infectious diseases like Tuberculosis, Hepatitis $\mathrm{C}$, pulmonary aspergillosis, and $\mathrm{H}$. pylori infection that could spread from sharing the mouthpieces among the $\mathrm{W}^{\prime} \mathrm{T}$ smokers. ${ }^{[4,31-35]}$ The WT smokers also resort to inhalation from nose, which is also harmful. Nemmer et al. 2015, demonstrated that sub-acute (five day) nose-only exposure to WTS resulted in pulmonary inflammation and oxidative stress without affecting pulmonary function, suggesting that inflammation and oxidative stress are early markers of WTS exposure that precedes airway dysfunction. ${ }^{[28]}$ Also, the long-term habitual abuse of WTS; just similar to regular cigarette smoking; is associated with lung, GI, and bladder malignancies besides pulmonary, cardiovascular, and hematological impairments. ${ }^{[4,36,37]}$

Despite this knowledge, the health risks of WTS remain largely unrecognized by the general public and thus the WTS is spreading dramatically. ${ }^{[4,13,38-40]}$ One main point that has led to widespread WTS is that there is no negative social norm against this type of smoking as is present against the cigarette. ${ }^{[4]}$ Thus the lay public continues to smoke in ignorance. The exotic, social, and group nature of this habit is appealing to young adults, regardless of gender or ethnicity; as a result, the WTS is rising fast among the youths compared to cigarette smoking. ${ }^{[4,41,42]}$ The younger generations have always been lured by the fancy advertisements in the media; the easy accessibility of the water pipes and hookah bars and also in the false belief that the passage of smoke though the water in water-pipes "purifies" the smoke of all harmful elements, which is absolutely wrong. ${ }^{[9]}$ The dissemination of healthcare information to the public is essential and thus the role of agencies involved in providing the same is very important, especially in resource poor settings. ${ }^{[4-46]}$

\section{CONCLUSIONS}

In conclusion, the WTS is a serious health issue and needs to be addressed. The role of all the stakeholders like health professionals, regulators, and the public at large is very important. There is an urgent need to explore the general public's knowledge and attitude towards waterpipe smoking. Health policy initiatives should be formulated to prevent marketing and licensing of hookah tobacco products and paraphernalia in local markets and shops. There should be a control over the easy accessibility of the hookah cafes. Also, the age limit should be imposed to curb the indulgence of the youths in this addiction. The WTS should be included in the anti-smoking campaigns. A discouragement of the practice at this stage would make certain that the evil is controlled, if not eliminated, before it actually sets its roots into our social norms. While there is a large amount of data on the short- and long-term effects of cigarette smoke, there is a paucity of data regarding WTS, thus further research into the extent and effects of WTS in the society is warranted. Mere policy making would not help rather actions must be taken at the grassroots level.

\section{Conflicts of interest}

The authors declare no conflicts of interest.

\section{REFERENCES}

1. Shihadeh A. Investigation of mainstream smoke aerosol of the argileh waterpipe. Food Chem Toxicol 2003;4:143-52.

2. Cobb CO, Khader Y, Nasim A, Eissenberg T. A multi-year survey of waterpipe and cigarette smoking on a U.S. university campus. J Am Coll Health 2012;60:521-7.

3. Chaouachi K. The Medical Consequences of Narghile (Hookah, Shisha) Use in the World. Rev Epidemiol Sante Publique 2007;55:165-70.

4. Aljarrah K, Ababneh ZQ, Al-Delaimy WK. Perceptions of hookah smoking harmfulness: predictors and characteristics among current hookah users. Tobacco Induced Diseases 2009;5:16.

5. Maziak W, Rastam S, Eissenberg T, Asfar T, Hammal F, Bachir ME, et al. Gender and smoking status-based analysis of views regarding waterpipe and cigarette smoking in Aleppo, Syria. Prev Med 2004;38:479-84.

6. Asfar T, Ward KD, Eissenberg T, Maziak W. Comparison of patterns of use, beliefs, and attitudes related to waterpipe between beginning and established smokers. BMC Public Health 2005;5:1-9.

7. Berestein L. Healthy or not; the Hooka Habit is Hot. Time International (South Pacific Edition) 2003;6:35

8. McNicoll T. Pipe smoking in cafes; Health hazards or cultural links. Newsweek International 2002;4:60.

9. WHO: World Health Organization. Waterpipe Tobacco Smoking: Health Effects, Research Needs and Recommended Actions by Regulators. Geneva, Switzerland 2005.Available from: http://www.who.int/tobacco/ global_interaction/tobreg/Waterpipe\%20recommendation_Final.pdf. Last accessed 2016 on January 15.

10. Maziak W, Ward KD, Eissenberg T: Interventions for waterpipe smoking cessation. Cochrane Database of Systematic Reviews 2007;(4):CD005549.

11. Barnett TE, Smith T, He Y, Soule EK, Curbow BA, Tomar SL, McCarty C. Evidence of emerging hookah use among university students: a crosssectional comparison between hookah and cigarette use. BMC Public 
Health 2013;13:302.

12. Sterling KL, Mermelstein R. Examining hookah smoking among a cohort of adolescent ever smokers. Nicotine Tobacco Res. 2011;13:1202-9.

13. Smith-Simone S, Maziak W, Ward KD, Eissenberg T. Waterpipe tobacco smoking: knowledge, attitudes, beliefs, and behavior in two U.S. samples. Nicotine Tobacco Res 2008;10:393-8.

14. Primack BA, Fertman C, Rice K, Adachi-Mejia A, Fine M. Waterpipe and cigarette smoking among college athletes in the United States. J Adolescent Health 2010;46:45-51.

15. Maziak W, Eissenberg T, Rastam S, Hammal F, Asfar T, Bachir ME, et al. Beliefs and attitudes related to narghile (waterpipe) smoking among university students in Syria. Ann Epidemiol 2004;14:646-54.

16. Tamim H, Al-Sahab B, Akkary G, Ghanem M, Tamim N, El Roueiheb $\mathrm{Z}$, et al. Cigarette and nargileh smoking practices among school students in Beirut, Lebanon. Am J Health Behav 2007;31:56-63.

17. WHO: World Health Organization. Tobacco Control Country Profiles. Available from URL:-http://www.who.int/tobacco/global_data/country_profiles/en/index.html. Last accessed 2016 on January 15.

18. Jackson D, Aveyard P. Waterpipe smoking in students: prevalence, risk factors, symptoms of addiction, and smoke intake. Evidence from one British university. BMC Public Health 2008;8:174.

19. Ward KD, Eissenberg T, Gray JN, Srinivas V, Wilson N, Maziak W. Characteristics of U.S. waterpipe users: a preliminary report. Nicotine Tob Res 2007;9:1339-46.

20. Primack BA, Sidani J, Agarwal AA, Shadel WG, Donny EC, Eissenberg TE. Prevalence of and associations with waterpipe tobacco smoking among U.S. university students. Ann Behav Med 2008;36:81-6.

21. Smith SY, Curbow B, Stillman FA. Harm perception of nicotine products in college freshmen. Nicotine Tob Res 2007;9:977-82.

22. Eissenberg T, Ward KD, Smith-Simone S, Maziak W. Waterpipe tobacco smoking on a U.S. College campus: prevalence and correlates. J Adolescent Health 2008;42:526-9.

23. Shihadeh A, Saleh R. Polycyclic aromatic hydrocarbons, carbon monoxide, "tar", and nicotine in the mainstream smoke aerosol of the narghile waterpipe. Food Chem Toxicol 2005;43:655-61.

24. Ward KD, Weg MW, Relyea G, Debon M, Klesges RC. Waterpipe smoking among American military recruits. Prev Med 2006;43:92-7.

25. Shihadeh A, Azar S, Antonios C, Haddad A. Towards a topographical model of narghile water-pipe cafe smoking: a pilot study in a high socioeconomic status neighborhood of Beirut, Lebanon. Pharmacol Biochem Behav 2004;79:75-82.

26. Kiter G, Ucan ES, Ceylan E, Kilinc O. Water-pipe smoking and pulmonary functions. Respir Med 2000;94:891-4.

27. Kandela P. Nargile smoking keeps Arabs in Wonderland. Lancet 2000;356:1175.

28. Nemmar A, Al Hemeiri A, Al Hammadi N, Yuvaraju P, Beegam S, Yasin $\mathrm{J}$, et al. Early pulmonary events of nose-only water pipe (shisha) smoking exposure in mice. Physiol Rep 2015;3:e12258.
29. Jensen PD, Cortes R, Engholm G, Kremers S, Gislum M. Waterpipe use predicts progression to regular cigarette smoking among Danish youth. Subst. Use Misuse 2010;45:1245-61.

30. The Dangers of Hookah Smoking. Available from: http://www.cdc.gov/ features/hookahsmoking/. Last accessed 2016 on January 15.

31. Hays JT. Is hookah smoking safer than smoking cigarettes? Available from: http://www.mayoclinic.org/healthy-lifestyle/quit-smoking/expertanswers/hookah/faq-20057920. Last accessed 2016 on January 15.

32. Knishkowy B, Amitai Y. Water-pipe (narghile) smoking: an emerging health risk behavior. Pediatrics 2005;116:113-9.

33. Maziak W, Ward KD, AfifiSoweid RA, Eissenberg T. Tobacco smoking using a waterpipe: a re-emerging strain in a global epidemic. Tob Control 2004;13:327-3.

34. Maziak W, Rastam S, Ibrahim I, Ward KD, Eissenberg T: Waterpipeassociated particulate matter emissions. Nicotine Tob Res 2008;10:51923.

35. Steentoft J, Wittendorf J, Andersen JR. Tuberculosis and water pipes as source of infection. Ugeskrift for Laeger 2006;168:904-7.

36. Bentur L, Hellou E, Goldbart A, Pillar G, Monovich E, Salameh M, et al. Laboratory and clinical acute effects of active and passive indoor group water-pipe (narghile) smoking. Chest 2014;145:803-9.

37. Hakim F, Hellou E, Goldbart A, Katz R, Bentur Y, Bentur L. The acute effects of water-pipe smoking on the cardiorespiratory system. Chest 2011;139:775-81.

38. Nakkash R, Khalil J. Health warning labelling practices on narghile (shisha, hookah) waterpipe tobacco products and related accessories. Tob Control 2010;19:235-9.

39. Maziak W. The waterpipe: time for action. Addiction 2008;103:1763-7.

40. Cobb C, Ward KD, Maziak W, Shihadeh AL, Eissenberg T. Waterpipe tobacco smoking: an emerging health crisis in the United States. Am J Health Behav 2010;34:275-85.

41. Saade G, AbouJaoude S, AfifiSoweid R, Warren CW, Jones NR. Patterns of tobacco use: results from GYTS in Lebanon. East Mediterr Health J 2008;14:1280-9.

42. Tamim H, Terro A, Kassem H, Ghazi A, Khamis TA, Hay MM, et al. Tobacco use by university students, Lebanon, 2001. Addiction 2003;98:9339.

43. Yadav S, Rawal G. Healthcare information for all-Is it achievable? IJSSR 2015;4:101-5.

44. Yadav S, Rawal G. Role of integrating community health workers in achieving healthcare information for all. IJSSR 2015;4:106-10.

45. Yadav S, Rawal G. The HIFA and the Health Phone: Laying the foundation for combating malnutrition in India. Int J Health Sci Res 2015;5:368-71.

46. Yadav S, Rawal G. Self-medication practice in low income countries. Int J Pharm Chem Anal 2015;2:139-42.

How to cite this article: Yadav S, Rawal G. Waterpipe tobacco smoking: A mini-review. J Transl Intern Med 2018; 6: 173-5. 